\title{
ANALISIS PERTUMBUHAN PENJUALAN, PROFITABILITAS DAN LIKUIDITAS TERHADAP KINERJA PERUSAHAAN OTOMOTIF YANG TERDAFTAR DI BURSA EFEK INDONESIA
}

\author{
Rina Milyati Yuniastuti \\ Sekolah Tinggi Ilmu Ekonomi Prasetiya Mandiri Lampung \\ Email : rinamilyati@gmail.com
}

\begin{abstract}
This research aims to determine the effect of partial sales growth on company performance, the influence of profitability on company performance and also the effect of liquidity on company performance and to know the simultaneous influence of sales growth, profitability and liquidity on company performance. which is listed on the Indonesian stock exchange. As for the results of this study it turns out that both partially and simultaneously have an effect. This means that sales growth, profitability and liquidity have a very big role in the company's performance.
\end{abstract}

Keywords: Sales Growth, Profitability, Liquidity, Performance

\section{PENDAHULUAN}

\subsection{Latar Belakang Masalah}

Kinerja perusahaan akan menjadi suatu hal yang sangat mendasar dalam suatu perusahaan khususnya dalam mengambil keputusan. Dengan adanya pertumbuhan penjualan yang semakin meningkat maka akan menjadikan kinerja perusahaan menjadi lebih bagus. Hal ini tidak terlepas dari keberhasilan investasi dimasa lalu.Pertumbuhan penjualan menjadikan suatu tombak keberhasilan dalam mencapai keuntungan,dan tidak menutup kemungkinan juga bahwa dengan kinerja perusahaan yang bagus maka kemampuan perusahaan dalam membayar kewajiban jangka pendek atau utang yang segera jatuh tempo pada saat ditagih secara keseluruhan dapat tepat waktu. Penilaian kinerja tidak hanya dilihat dari rutinnya barang keluar masuk akan tetapi juga bisa dilihat salah satunya dengan menerbitkan laporan keuangan setiap tahunnya. Dari laporan keuangan itu akan terlihat kondisi keuangan yang sebenarnya dari peusahaan tersebut. Menurut IAI (2007) kinerja keuangan adalah kemampuan perusahaan dalam mengelola dan mengendalikan sumberdaya yang dimilikinya. Gambaran tentang kondisi keuangan suatu perusahaan yang dianalisis dengan alat alat analisis keuangan akan menjadikan suatu kinerja keuangan perusahaan dapat dilihat dengan baik.Kinerja keuangan terkait salah satunya dengan pertumbuhan penjualan dengan diproksi growth sedangakan pada profitabilitas atau profit dimana alat analisis yang digunakan dalam penelitian ini adalah rasio profitabilitas.Dalam rasio ini yang digunakan adalah ROA . Hal ini karena ROA /return on assets akan menggambarkan keuntungan dari aset yang dimilikinya, sedangkan likuiditas justru menggambarkan total aktiva dari hutang lancar dengan proksi Current Rasio. Dalam kinerja keuangan perusahaan juga menentukan ukuran yang dapat mengukur keberhasilan suatu organisasi dalam menghasilkan laba.Karena dengan adanya laba yang meningkat dari tahun ke tahun berarti menandakan bahwa perusahaan tersebut mempunyai kinerja yang baik. Dan dengan keberhasilan suatu perusahaan dalam mencapai tujuan perusahaan merupakan prestasi manajemen.

\subsection{Perumusan Masalah}

1. Apakah terdapat pengaruh Pertumbuhan penjualan terhadap kinerja perusahaan Otomotif Tbk.?

2. Apakah terdapat pengaruh Profitabilitas terhadap kinerja perusahaan Otomotif Tbk.? 
3. Apakah terdapat pengaruh Likuiditas terhadap kinerja perusahaan Otomotif Tbk.?

4. Apakah Pertumbuhan penjualan, profitabilitas dan likuiditas berpengaruh terhadap kinerja perusahaan Otomotif Tbk.?

\subsection{Tujuan Penelitian}

1. Untuk menganalisis pengaruh Pertumbuhan penjualan terhadap kinerja perusahaan Otomotif Tbk.

2. Untuk menganalisis pengaruh Profitabilitas terhadap kinerja perusahaan Otomotif Tbk.

3. Untuk menganalisis pengaruh Likuiditas terhadap kinerja perusahaan Otomotif Tbk.

4. Untuk menganalisis Pertumbuhan penjualan,profitabilitas dan likuiditas berpengaruh terhadap kinerja perusahaan Otomotif Tbk.

\section{TINJAUAN PUSTAKA}

\subsection{Pertumbuhan Penjualan}

Mencerminkan

manifestasi

keberhasilan investasi periode masa lalu,dan dapat dijadikan sebagai prediksi permintaan dan daya saing perusahaan dalam satu industri. Laju pertumbuhan suatu perusahaan akan mempengaruhi kemampuan mempertahankan keuntungan dalam mendanai kesempatan pada masa yang akan datang (Barton et al.1989).

Definis Growth menurut Kasmir (2014:107) adalah sebagai berikut Rasio pertumbuhan (growth Ratio) merupakan rasio yang menggambarkan kemampuan perusahaan dalam mempertahankan posisinya di dalam indutri dan dalam perkembangan ekonomi secara umum. Rasio pertumbuhan ini dilihat dari berbagai segi sales (penjualan),earning after tax (EAT),laba per lembar saham ,dividen per lembar saham, dan harga pasar perlembar saham.Rasio ini terdiri dari kenaikan penjualan,kenaikan laba bersih ,earning per share dan kenaikan deviden per share.

\subsection{Laporan Keuangan}

Laporan keuangan yang disajikan oleh perusahaan dalam beberapa kurun waktu dapat digunakan untuk memprediksi laba atau dividen diwaktu yang akan datang. Dari sudut pandang investor analis laporan keuangan dapat digunakan sebagai alat prediksi prospek masa depan perusahaan tersebut. Sementara itu dari sudut pandang manajemen selain alat prediksi antisipasi masa depan, juga sebagai dasar untuk perencanaan tindakan terhadap faktor-faktor kunci yang sering mempengaruhi peristiwa pada masa lalu sebagai pedoman kedepan.

\section{a. Sifat dan Keterbatasan Laporan Keuangan}

Dalam Ikatan Akuntan Indonesia secara terperinci menjelaskan tentang sifat dan keterbatasan laporan keuangan sebagai berikut:

1. Laporan keuangan yang bersifat sejarah yang tidak lain merupakan kejadiankejadian yang lewat,maka terdapat keterbatasan.

2. Laporan keuangan bersifat umum dan bukan untuk memenuhi kebutuhan tiaptiap pemakai.

3. Laporan keuangan itu sebagai hasil pemakaian setelah timbulnya hak dan kewajiban dalam akuntansi. Dalam proses penyusunannya tidak terlepas dari penaksiran dan pertimbanganpertimbangan.

4. Laporan keuangan lebih menekankan bagaimana keadaan sebenarnya peristiwa-peristiwa dilihat dari sudut ekonomi daripada berpegang pada formilnya.

\subsection{Analisis Ratio Keuangan}

Ada dua cara dalam menilai rasio keuangan agar lebih berarti :

1) Menilai rasio keuangan antar waktu (sebaiknya waktu yang cukup lama, misal 5 tahun agar dapat diketahui arah pergerakannya)

2) Membandingkan rasio keuangan perusahaan dengan rasio industri. Penilaian ini akan dapat menilai perusahaan apakah lebih baik atau tidak dibandingkan dengan pesaing kita. 


\section{Rasio likuiditas ( Liquidity Ratio )}

Merupakan rasio yang menggambarkan kemampuan perusahaan dalam memenuhi kewajiban (utang) jangka pendek. Artinya apabila perusahaan ditagih, perusahaan akan mampu untuk memenuhi utang tersebut, terutama utang yang sudah jatuh tempo. Dengan kata lain ,rasio likuiditas berfungsi untuk menunjukkan atau mengukur kemampuan perusahaan dalam memenuhi kewajibannya yang sudah jatuh tempo ,baik kewajiban kepada pihak luar perusahaan (likuiditas badan usaha) maupun didalam perusahaan (likuiditas perusahaan).

\section{a. Jenis-jenis Rasio Likuiditas}

Dalam praktiknya ,untuk mengukur rasio keuangan secara lengkap, dapat menggunakan jenis-jenis rasio likuiditas yang ada Jenis-jenis rasio likuiditas yang dapat digunakan perusahaan untuk mengukur kemampuan, yaitu :

1. Rasio lancar ( current ratio )

Rasio lancar atau (current ratio) merupakan rasio untuk mengukur kemampuan perusahaan dalam membayar kewajiban jangka pendek atau utang yang segera jatuh tempo pada saat ditagih secara keseluruhan. Dengan kata lain, seberapa banyak aktiva lancar yang tersedia untuk menutupi kewajiban jangka pendek yang segera jatuh tempo.

Current ratio $=\frac{\text { Aktiva Lancar }}{\text { Hutang lancar }}$

\section{Rasio Cepat ( quick Ratio)}

Rasio cepat ( quick Ratio ) atau rasio sangat lancar atau acid test ratio merupakan rasio yang menunjukkan kemampuan perusahaan dalam memenuhi atau membayar kewajiban atau utang lancar ( utang jangka pendek) dengan aktiva lancar tanpa memperhitungkan nilai sediaan (inventory). Artinya nilai sediaan kita abaikan, dengan cara dikurangi dari nilai total aktiva lancar.

Quick ratio $=\frac{\text { Aktiva Lancar }- \text { Persediaan }}{\text { Hutang lancar }}$
3. Rasio Kas (Cash Ratio)

Rasio kas atau cash ratio merupakan alat yang digunakan untuk mengukur seberapa besar uang kas yang tersedia untuk membayar utang. Ketersediaan uang kas dapat ditunjukkan dari tersedianya dana kas atau yang setara dengan kas seperti rekening giro atau tabungan di bank ( yang dapat ditarik setiap saat).

$$
\text { Cash ratio }=\frac{\text { Kas }+ \text { Bank }}{\text { Hutang lancar }}
$$

4. Rasio Perputaran Kas ( Cash turn over)

Rasio perputaran kas (Cash turn over ) berfungsi untuk mengukur tingkat kecukupan modal kerja perusahaan yang dibutuhkan untuk membayar tagihan dan membiayai penjualan. Artinya rasio ini digunakan untuk mengukur tingkat ketersediaan kas untuk membayar tagihan (utang) dan biaya-biaya yang berkaitan dengan penjualan. Hasil perhitungan rasio perputaran kas dapat diartikan sebagai berikut:

a. Apabila rasio perputaran kas tinggi,ini berarti, ketidakmampuan perusahaan dalam membayar tagihannya.

b. Sebaliknya apabila rasio perputaran kas rendah, dapat diartikan kas yang tertanam pada aktiva yang sulit dicairkan dalam waktu singkat sehingga perusahaan harus bekerja keras dengan kas yang lebih sedikit.

$$
\text { Rasio Perputaran Kas }=\frac{\text { Penjualan Bersih }}{\text { Modal Kerja Bersih }}
$$

\section{b. Hasil pengukuran Kinerja}

Perusahaan mengetahui baik atau tidaknya kondisi keuangan perusahaan dilihat dari standard Industri yang ditetapkan dalam setiap jenis rasio keuangan yang ada, dari pengukuran Rasio kita dapat melihat kondisi posisi keuangan perusahaan seperti yang terlihat dalam tabel Berikut ini : 
Tabel 1

Hasil Pengukuran Standard Industri Perusahaan

\begin{tabular}{lll}
\hline No & \multicolumn{1}{c}{ Jenis Rasio } & \multicolumn{1}{c}{$\begin{array}{c}\text { Standard } \\
\text { Industri }\end{array}$} \\
\hline 1 & Current Ratio & 2 kali $(200 \%)$ \\
\hline 2 & Quick Ratio & 1,5 kali $(150 \%)$ \\
\hline 3 & Cash Ratio & $50 \%$ \\
\hline 4 & Cash turn over & $10 \%$ \\
\hline 5 & $\begin{array}{l}\text { Inventory to net } \\
\text { working capital }\end{array}$ & $12 \%$ \\
\hline
\end{tabular}

Sumber : : Analisis laporan keuangan, Kasmir (2014)

\section{Rasio Aktivitas ( activity ratio)}

Merupakan rasio yang digunakan untuk mengukur efektivitas perusahaan dalam menggunakan aktiva yang dimilikinya. Atau dapat pula dikatakan rasio ini digunakan untuk mengukur tingkat efisiensi (efektivitas) pemanfaatan sumber daya perusahaan. Efisiensi yang dilakukan misalnya dibidang penjualan , sediaan,penagihan piutang dan efisiensi dibidang lainnya. Rasio aktivitas juga digunakan untuk menilai kemampuan perusahaan dalam melaksanaan aktivitas sehari-hari. Dari hasil pengukuran dengan rasio aktivitas akan terlihat apakah persahaan lebih efisien dan efektif dalam mengelola aset yang dimilikinya atau mungkin justru sebaliknya.

\section{a. Jenis-Jenis Rasio Aktivitas}

Rasio Aktivitas yang dapat digunakan manajemen untuk mengambil keputusan terdiri dari beberapa jenis. Penggunaan rasio yang diinginkan sangat tergantung dari keinginan manajemen perusahaan. Artinya lengkap tidaknya rasio aktivitas yang akan digunakan tergantung dari kebutuhan dan tujuan yang ingin dicapai pihak manajemen perusahaan tersebut. Secara umum apabila seluruh rasio aktivitas yang ada digunakan,akan mampu memperlihatkan efektivitas perusahaan secara maksimal,jika dibandingkan dengan penggunaan hanya sebagian saja. Berikut ini beberapa jenis-jenis rasio aktivitas yang dirangkum dari beberapa ahli keuangan, yaitu :
1. Perputaran Piutang ( Receivable turn over)

Perputaran piutang merupakan rasio yang digunakan untuk mengukur berama lama penagihan piutang selama satu periode atau berapa kali dana yang ditanam dalam piutang ini berputar dalam dalam satu periode. Semakin tinggi rasio menunjukkan bahwa modal kerja yang ditanamkan dalam piutang semakin rendah (bandingkan dengan rasio tahun sebelumnya) dan tentunya kondisi ini bagi perusahaan semakin baik. Sebaliknya jika rasio semakin rendah ada over investment dalam piutang . hal yang jelas adalah rasio perputaran piutang member pemahaman tentang kualitas piutang dan kesuksesan penagihan piutang. Cara untuk mencari rasio ini adalah dengan membandingkan antara penjualan kredit dengan rata-rata piutang.

Perputaran Piutang $=\frac{\text { Penjualan Kredit }}{\text { Rata }- \text { rata Piutang }}$

2. Perputaran Sediaan (Inventory Turn Over)

Perputaran sediaan merupakan rasio yang digunakan untuk mengukur berapa kali dana yang ditanam dalam sediaan (inventory) ini berputar dalam satu periode.Cara menghitung rasio perputaran sediaan dilakukan dengan dua cara yaitu : pertama ,membandingkan antara harga pokok barang yang dijual dengan nilai sediaan dan kedua, membandingkan antara penjualan nilai sediaan. Apabila rasio yang diperoleh tinggi , ini menunjukkan perusahaan bekerja secara efisien dan likuid persediaan semakin baik.

$$
\text { Inventory turn over }=\frac{\text { Harga pokok barang yang dijual }}{\text { Persediaan }}
$$

3. Perputaran Modal Kerja ( Working Capital Turn Over)

Perputaran modal kerja atau working capital turn over merupakan salah 
satu rasio untuk mengukur atau menilai keefektifan modal kerja perusahaan selama periode tertentu. Artinya seberapa banyak modal kerja berputar selama satu periode atau dalam suatu periode. Untuk mengukur rasio ini, kita membandingkan antara penjualan dengan modal kerja atau dengan modal kerja rata-rata. Dari hasil penilaian,apabila perputaran modal kerja yang rendah ,dapat diartikan perusahaan sedang kelebihan modal kerja. Hal ini mungkin disebabkan karena rendahnya perputaran persediaan atau piutang atau saldo kas yang terlala besar. Cara untuk mencari perputaran modal kerja adalah sebagai berikut :

Perputaran modal kerja $=\frac{\text { Penjualan Bersih }}{\text { Modal kerja rata }- \text { rata }}$

\section{Fixes Assets Turn Over}

Merupakan rasio yang digunakan untuk mengukur berapa kali dana yang ditanamkan dalam aktiva tetap berputar dalam satu periode.Atau dengan kata lain,untuk mengukur apakah perusahaan sudah menggunakan kapasitas aktiva tetap sepenuhnya tau belum. Untuk mencari rasio ini, caranya adalah membandingkan antara penjualan bersih dengan aktiva tetap dalam suatu periode.

Fixed Assets turn over $=\frac{\text { Penjualan }}{\text { Total Aktiva Tetap }}$

\section{Total Assets Turn Over}

Merupakan rasio yang digunakan untuk mengukur perputaran semua aktiva yang dimiliki perusahaan dan mengukur berapa jumlah penjualan yang diperoleh dari tiap rupiah aktiva.

Total Assets turn over $=\frac{\text { Penjualan }}{\text { Total Aktiva }}$

\section{b. Hasil pengukuran kinerja}

Perusahaan mengetahui baik atau tidaknya kondisi keuangan perusahaan dilihat dari standard Industri yang ditetapkan dalam setiap jenis rasio keuangan yang ada, dari pengukuran Rasio kita dapat melihat kondisi posisi keuangan perusahaan seperti yang terlihat dalam tabel Berikut ini :

Tabel 2.

Hasil Pengukuran Kinerja

\begin{tabular}{cll}
\hline No & \multicolumn{1}{c}{ Jenis Rasio } & $\begin{array}{c}\text { Standard } \\
\text { Industri }\end{array}$ \\
\hline 1 & Receivable turn over & 15 kali \\
\hline 2 & Inventory turn Over & 20 kali \\
\hline 3 & Working capital turn over & 6 kali \\
\hline 4 & Fixed asset turn over & $5 \mathrm{kali}$ \\
\hline 5 & Total asset turn over & 2 kali \\
\hline $\begin{array}{l}\text { Sumber : Analisis Laporan keuangan , Kasmir } \\
\text { (2014) }\end{array}$
\end{tabular}

\section{Rasio Profitabilitas}

Merupakan rasio untuk menilai kemampuan perusahaan dalam mencari keuntungan. Rasio ini juga memberikan ukuran tingkat efektivitas manajemen suatu perusahaan. Hal ini ditunjukkan oleh laba yang dihasilkan dari penjualan dan pendapatan investasi. Intinya adalah penggunaan rasio ini menujukkan efisiensi perusahaan. Penggunaan rasio profitabilitas dapat dilakukan dengan menggunakan perbandingan antara berbagai komponen yang ada dalam laporan keuangan, terutama laporan keuangan neraca dan laba rugi. Tujuannya adalah agar terlihat perkembangan perusahaan dalam rentang waktuu tertentu, baik penurunan atau kenaikan,sekaligus mencari penyebab perubahan tersebut.

\section{a. Jenis-jenis Rasio Profitabilitas}

Sesuai dengan tujuan yang hendak dicapai , terdapat beberapa jenis rasio profitabilitas yang digunakan. Masingmasing jenis rasio profitabilitas digunakan untuk menilai serta mengukur posisi keuangan perusahaan dalam suatu periode tertentu atau untuk beberapa periode.Penggunaan seluruh atau sebagian rasio profitabilitas tergantung dari kebijakan manajemen. Jelasnya,, semakin lengkap jenis rasio yang digunakan,semakin sempurna hasil yang akan dicapai . artinya pengetahuan tentang kondisi dan posisi profitabilitas 
perusahaan dapat diketahui secara sempurna.

1. Profit Margin on Sales

Profit margin on sales atau ratio profit margin atau margin laba atas penjualan merupakan salah satu rasio yang digunakan untuk mengukur margin laba atas penjualan. Cara pengukuran rasio ini adalah dengan membandingkan laba bersih setelah pajak dengan penjualan bersih . rasio ini juga dikenal dengan nama profit margin.Terdapat dua rumus untk mencari profit margin, yaitu sebagai berikut :

1) Untuk margin laba kotor dengan rumus:

Profit margin $=\frac{\text { Penjualan bersih }- \text { harga pokok penjualan }}{\text { Sales }}$

Margin laba kotor menunjukkan laba yang relative terhadap perusahaan, dengan cara penjualan bersih dikurangi harga pokok penjualan. Rasio ini merupakan cara untuk penetapan harga pokok penjualan .

2) Untuk margin laba bersih dengan rumus :

Net Profit margin $=\frac{\text { Earning After interest and Tax }(\text { EAIT })}{\text { Sales }}$ Margin laba bersih merupakan ukuran keuntungan dengan membandingkan antara laba setelah bunga dan pajak dibandingkan dengan penjualan. Rasio ini menunjukkan pendapatan bersih perusahaan atas penjualan.

2. Return On invesment (ROI) /Return On Assets Rasio (ROA)

Return On invesment atau return on asset menunjukan kemampuan perusahaan menghasilkan laba dari aktiva yang dipergunakaan. Dengan mengetahui rasio ini, akan dapat diketahui apakah perusahan efesien dalam memanfaatkan aktivanya dalam kegiatan operasional perusahan rasio ini juga memberikan ukursn yang lebih bbaik atas profitabilitas perusahaan karena Return on Eguity menunjukan efektivitas manajemen dalam menggunakan aktiva untuk memperoleh pendapatan.

$$
\text { ROI }=\frac{\text { Laba setelah pajak }}{\text { Total Assets }} \times 100 \%
$$

3. Return on Equity ( ROE)

Return on Equity (ROE) adalah rasio profitabilitas yang membandingkan antar laba bersih (net profit) perusahaan dengan aset bersihnya (ekuitas atau modal). Rasio ini mengukur berapa banyak keuntungan yang dihasilkan oleh Perusahaan dibandingkan dengan modal yang disetor oleh Pemegang Saham

$$
\text { Return on Equity }=\frac{\text { Laba bersih }}{\text { Ekuitas }}
$$

4. Laba Per Lembar Saham Biasa ( Earning per Share of Common Stock )

Rasio laba per lembar saham atau disebut juga rasio nilai buku merupakan rasio untuk mengukur keberhasilan manajemen dalam mencapai keuntungan bagi pemegang saham. Rasio yang rendah berarti manajemen belum berhasil untuk memuaskan pemegang saham ,sebaliknya dengan rasio yang tinggi ,kesejahteraan pemegang saham meningkat. Dengan pengertian lain, tingkat pengembalian yang tinggi. Keuntungan bagi pemegang saham adalah jumlah keuntungan setelah dipotong pajak. Keuntungan yang tersedia bagi pemegang saham biasa adalah jumlah keuntungan dikurangi pajak, deviden dan dikurangi hak-hak lain untuk pemegang saham prioritas.

Laba per Lembar Saham $=\frac{\text { Laba saham biasa }}{\text { Saham biada yang beredar }}$

\section{b. Hasil pengukuran kinerja}

Perusahaan mengetahui baik atau tidaknya kondisi keuangan perusahaan dilihat dari standard Industri yang ditetapkan dalam setiap jenis rasio 
keuangan yang ada, dari pengukuran Rasio kita dapat melihat kondisi posisi keuangan perusahaan seperti yang terlihat dalam tabel Berikut ini :

Tabel 3.

Hasil Pengukuran Kinerja

\begin{tabular}{|c|c|c|}
\hline No & Jenis Rasio & $\begin{array}{c}\text { Standard } \\
\text { Industri }\end{array}$ \\
\hline 1 & $\begin{array}{ll}\text { Net } & \text { Profit } \\
\text { margin } & \end{array}$ & $20 \%$ \\
\hline 2 & $\begin{array}{l}\text { Return on } \\
\text { investment }\end{array}$ & $30 \%$ \\
\hline 3 & $\begin{array}{l}\text { Return on } \\
\text { Equity }\end{array}$ & $40 \%$ \\
\hline 4 & $\begin{array}{l}\text { Fixed asset } \\
\text { turn over }\end{array}$ & 5 kali \\
\hline 5 & $\begin{array}{l}\text { Total asset } \\
\text { turn over }\end{array}$ & 2 kali \\
\hline
\end{tabular}

Sumber : Analisis Laporan Keuangan , Kasmir (2014)

\subsection{Hipotesis}

1. Pertumbuhan penjualan berpengaruh terhadap kinerja perusahaan Otomotif Tbk..

2. Profitabilitas berpengaruh terhadap kinerja perusahaan Otomotif Tbk.

3. Likuiditas berpengaruh terhadap kinerja perusahaan Otomotif Tbk..

4. Pertumbuhan penjualan,profitabilitas dan likuiditas berpengaruh terhadap kinerja perusahaan Otomotif Tbk..

\section{METODOLOGI PENELITIAN}

\subsection{Populasi dan Sampel Penelitian}

Populasi yang diambil dalam penelitian ini adalah perusahaan otomotif yang sudah terdaftar di Bursa Efek Indonesia ( BEI ). Sampel yang digunakan perusahaan menggunakan metode pruposive sampling yaitu teknik pengambilan sampel sumber data dengan pertimbangan tertentu.,Sugiyono (2011:126). Dan pertimbangan yang digunakan adalah sebagai berikut :

1. Perusahaan otomotif yang terdaftar di Bursa Efek Indonesia (BEI) tahun 2013 2016.

Menyajikan laporan keuangan yang terlampir di tahun 2013- 2016.
Tabel 4.

Daftar Kriteria Sampel Penelitian

\begin{tabular}{|c|l|c|}
\hline NO & \multicolumn{1}{|c|}{ Keterangan } & Jumlah \\
\hline 1 & $\begin{array}{l}\text { Jumlah perusahaan } \\
\text { otomotif yang terdaftar di } \\
\text { Bursa Efek Indonesia }\end{array}$ & 18 \\
\hline 2 & $\begin{array}{l}\text { Perusahaan yenyajikan yang } \\
\text { meuangan tahun 2013- }\end{array}$ & 13 \\
\hline 3 & $\begin{array}{l}\text { Jumlan sampel penelitian } \\
\text { Jumlan }\end{array}$ & 13 \\
\hline
\end{tabular}

\subsection{Teknik Pengumpulan Data}

Teknik Pengumpulan data dalam penelitian ini adalah teknik dokumentasi yaitu dengan cara mengumpulkan data sekunder yang diperoleh dari berbagai sumber. Dalam penelitian ini penulis mengumpulkan data sekunder berupa laporan keuangan tahunan pada perusahaan otomotif yang telah terdaftar di Bursa Efek Indonesia melalui situs resmi BEI www.idx.co.id.

\subsection{Teknik analisis data}

Teknik analisis data yang digunakan dalam penelitian ini ada dua yaitu:Analisis Kualitatif adalah data yang didapatkan akan dianalisis dengan penilaian teoritis dan logis sesuai dengan pembuktian secara kuantitatifnya. Serta Analisis Kuantitatif adalah data yang dianalisis secara pembuktian angka angka sesuai dengan data yang di dapat dalam penelitian.

\section{Variabel Penelitian}

Variabel yang digunakan dalam penelitian ini adalah Pertumbuhan Penjualan,ROA dan Current Rasio terhadap Kinerja sebagai berikut:

1) Pertumbuhan Penjualan

Meningkatnya penjualan dibandingkan dengan total penjualan secara keseluruhan

2) Return On Assets (ROA) merupakan rasio yang menunjukkan seberapa besar kontribusi assets dalam menciptakan laba bersih

$$
\mathrm{ROA}=\frac{\text { Laba setelah Pajak }}{\text { Total Assets }} \times 100 \%
$$


3) Current Ratio (CR)

Current ratio adalah alat yang digunakan untuk mengukur kemampuan perusahaan dalam membayar kewajiban jangka pendek.

$$
\mathrm{CR}=\frac{\text { Aktiva Lancar }}{\text { Utang Lancar }}
$$

\section{HASIL PENELITIAN DAN PEMBAHASAN}

4.1 Hasil Uji Regresi Linier Berganda

Hasil uji regresi linier berganda yang disajkan pada tabel 1 berikut ini:

Tabel 5.

Hasil Uji Regresi Linier Berganda

\begin{tabular}{|c|c|c|c|c|c|c|}
\hline \multirow{2}{*}{ Mode } & & \multicolumn{2}{|c|}{ Unstandardized Coefficients } & $\begin{array}{l}\text { Standardized } \\
\text { Coefficients }\end{array}$ & \multirow{2}{*}{$t$} & \multirow{2}{*}{ Sig. } \\
\hline & & B & Std. Error & Beta & & \\
\hline \multirow{4}{*}{1} & (Constant) & 518.590 & 286.999 & & 1.807 & .104 \\
\hline & GROWTH & .003 & .013 & .046 & .229 & .024 \\
\hline & ROA & -2.852 & .674 & -.846 & -4.231 & .002 \\
\hline & CR & .023 & .243 & .261 & .291 & .003 \\
\hline
\end{tabular}

Sumber : data diolah 2018

Dari tabel diatas didapat persamaan regresi linier berganda sebagai berikut:

Kinerja $=518.590+0.003 \times 1-$ $2.852 \times 2+0.023 \times 3$

Interprestasi yang di dapat dinyatakan dari persamaan diatas sebagai berikut:

1. Nilai kontantan sebesar 518.590 yang artinya jika nilai Growth, ROA dan CR memiliki nilai sama dengan nol maka nilai kinerja sebesar 518.590

2. Nilai Growth sebesar 0.003 Dengan koefisien positif yang artinya setiap Growth meningkat satu satuan maka kinerja akan mengalami peningkatan sebesar 0.003 satuan dengan asumsi bahwa variabel bebas lainnya dianggap konstan.

3. Nilai ROA sebesar -2.852 Dengan koefisien negatif yang artinya setiap ROA menurun satu satuan maka Kinerja akan mengalami penurunan sebesar 2.852 satuan dengan asumsi bahwa variabel bebas lainnya dianggap konstan.

4. Nilai CR sebesar 0.023 Dengan koefisien positif yang artinya setiap CR meningkat satu satuan maka Kinerja akan mengalami peningkatan sebesar 0.023 satuan dengan asumsi bahwa variabel bebas lainnya dianggap konstan.

\section{Hasil Model Summary}

Dari tabel 2 diatas hasil $R$ - Square diperoleh sebesar 0,763 yang akan diubah menjadi prosentase sebesar $76,3 \%$ yang artinya Growth,ROA dan Current rasio memberikan pengaruh terhadap Kinerja sedangkan sisanya dipengaruhi oleh faktor lain yang tidak diteliti.

Tabel 2.

Model Summary Perusahaan Otomotif

\begin{tabular}{lrrrr}
\hline Model & R & R Square & Adjusted R Square & Std. Error of the Estimate \\
\hline 1 & $.874^{a}$ & .763 & .711 & 297.340 \\
\hline
\end{tabular}

Sumber : data diolah 2018

\subsection{Hasil Uji Simultan}

Dari tabel dibawah di dapat signifikansi untuk perusahaan Otomotif sebesar $=0,002$ yang berarti < signifikansi $=0,05$ ini berarti secara simultan antara variabel independent dan variabel 
dependent mempunyai pengaruh secara bersama sama atau secara simultan. Dan ini berarti Ho ditolak. Untuk Uji Simultan ( uji F) didapat pada tabel berikut ini :

Tabel 3.

ANOVA Perusahaan Otomotif

\begin{tabular}{llrrrrr}
\hline Model & & $\begin{array}{c}\text { Sum of } \\
\text { Squares }\end{array}$ & df & Mean Square & $F$ & Sig. \\
\hline \multirow{3}{*}{1} & \multicolumn{1}{c}{\begin{tabular}{l} 
Regression \\
\cline { 2 - 7 }
\end{tabular}} & 2564956.878 & 2 & 1282478.439 & 14.506 & $.002^{\mathrm{b}}$ \\
\cline { 2 - 7 } & Residual & 795698.039 & 9 & 88410.893 & & \\
\hline
\end{tabular}

Sumber : Data diolah 2018

\section{SIMPULAN DAN SARAN}

\subsection{Simpulan}

1. Pertumbuhan penjualan dengan proksi growth berpengaruh terhadap kinerja perusahaan otomotif

2. Profitabilitas dengan proksi ROA berpengaruh terhadap kinerja perusahaan otomotif

3. Likuiditas dengan proksi Current Rasio berpengaruh terhadap kinerja perusahaan otomotif

4. Pertumbuhan penjualan,Profitabilitas dan Likuiditas berpengaruh secara bersama sama terhadap kinerja Perusahaan Otomotif atau berpengaruh secara simultan.

\subsection{Saran}

Disarankan agar perusahaan Otomotif lebih harus berusaha untuk meningkatkan penjualan dan mampu dalam membayar kewajiban jangka pendek dan menilai hutang dengan ekuitas secara baik serta sedapat mungkin dapat memperoleh laba bersih.

\section{DAFTAR PUSTAKA}

Fahmi, Irham,2010. Analisis Laporan Keuanga, Edisi Pertama. Alfabeta. Bandung.

Hery. 2015. Analisis Laporan Keuangan, PT Buku Seru. Cet 1. Yogyakarta.

Kasmir. 2014. Analisis Laporan Keuangan, Edisi Pertama (Revisi). PT RajaGrafindo Persada. Jakarta.

Kuncoro, Mudrajad. 2011. Metode Kuantitatif, Edisi Empat. Unit Penerbit dan Percetakan Sekolah Tinggi IImu Manajemen. Yogyakarta
Munawir. 2010. Analisa Laporan Keuangan, Edisi Keempat. Liberty. Yogyakarta.

Milyati, rina .(2017).Uji parsial current rasio, debt to equity rasio dan inventory turnover terhadap return on assets pada perusahaan makanan dan minuman yang terdaftar di bursa efek indonesia. Jurnal ilmiah gema ekonomi:7(1) ,951964.

Milyati,rina.(2017).Pengaruh Dominan current ratio, debt to assets ratio,total assets turnover terhadap return on equity pada perusahaan makanan dan minuman di bursa efek Indonesia .Optimum: Jurnal ekonomi dan pembangunan:7(1),27 -38.

Milyati ,rina.(2016).Pengaruh Dominan cash ratio dan debt to assets rastio terhadap Return on Equity dan return on assets pada perusahaan transportasi di bursa efek Indonesia,Jurnal Manajemen Magister Darmajaya:2(1),95-104.

Pura, Rahman. 2013. Pengantar Akuntansi 1 : Pendekatan Siklus Akuntansi, Edisi Pertama. Erlangga. Jakarta.

Ribo, Agustinus.2013.Analisis Laporan Keuangan untuk menilai Kinerja Keuangan Perusahaan Telekominikasi Yang Terdaftar Di Bursa Efek Indonesia (Studi Pada PT Telekomunikasi Indonesia TBK),Skripsi ,Fak. Ekonomi Dan Bisnis,Universitas Hasanuddin ,Makasar

Sartono,A.2001.Manajemen Keuangan: Teori dan Aplikasi.Edisis Keempat.Cetakan Pertama.Yogyakarta:BPFE 
ISSN 2086-9592

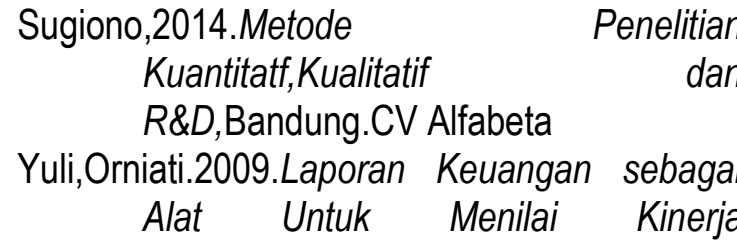

Keuangan.Jurnal

Bisnis,Tahun 14 Nomor 3 Nopember 2009

www.idx.co.id 